\title{
1 Genetically predicted serum vitamin D and COVID-19: a Mendelian randomization study
}

\author{
Bonnie K Patchen ${ }^{1}$, Andrew G Clark ${ }^{2}$, Dana B Hancock ${ }^{3}$, Nathan Gaddis ${ }^{3}$,
} Patricia A Cassano ${ }^{1,4}$

$4 \quad{ }^{1}$ Division of Nutritional Sciences, Cornell University, Ithaca NY, United States 14853

$5 \quad{ }^{2}$ Department of Molecular Biology and Genetics, Cornell University, Ithaca NY, United States

$6 \quad 14853$

$7 \quad{ }^{3}$ GenOmics, Bioinformatics and Translational Research Center, Research Triangle Institute

8 International, Research Triangle Park, NC, United States 27709-2194

$9{ }^{4}$ Weill Cornell Medicine, Department of Population Health Sciences, Division of Epidemiology, 10 NY, NY, United States 10065

11 Correspondence to: P.A. Cassano pac6@ cornell.edu 


\section{ABSTRACT}

Objectives: To investigate causality of the association of serum vitamin D with the risk and severity of COVID-19 infection.

Design: Two-sample Mendelian randomization study.

Setting: Summary data from genome-wide analyses in the population-based UK Biobank and SUNLIGHT Consortium, applied to meta-analyzed results of genome-wide analyses in the COVID-19 Host Genetics Initiative.

Participants: 17,965 COVID-19 cases including 11,085 laboratory or physician confirmed cases, 7,885 hospitalized cases, and 4,336 severe respiratory cases, and 1,370,547 controls, primarily of European ancestry.

Exposures: Genetically predicted variation in serum vitamin D status, based on genome-wide significant single nucleotide polymorphisms (SNPs) associated with serum vitamin D or risk of vitamin D deficiency/insufficiency.

Main outcome measures: Susceptibility to and severity of COVID-19 infection, including severe respiratory infection and hospitalization.

Results: Mendelian randomization analysis, powered to detect moderate effects comparable to those seen in observational studies, provided little to no evidence for an effect of genetically predicted serum vitamin D on susceptibility to or severity of COVID-19 infection. Using SNPs in loci related to vitamin D metabolism as proxies for serum vitamin D concentration, the odds ratio for a standard deviation increase in serum vitamin D was 1.04 (95\% confidence interval 0.92 to 1.18 ) for any COVID-19 infection versus population controls, 1.05 (0.84-1.31) for hospitalized COVID-19 versus population controls, 0.96 (0.64 to 1.43) for severe respiratory COVID-19 versus population controls, 1.15 (0.99 to 1.35) for COVID-19 positive versus COVID-19 negative, and 1.44 (0.75 to 2.78) for hospitalized COVID-19 versus non-hospitalized COVID-19. Results were similar in analyses that used all SNPs with genome-wide significant associations with serum vitamin D (i.e., including SNPs in loci with no known relationship to vitamin D metabolism) and in analyses using SNPs with genome-wide significant associations with risk of vitamin D deficiency or insufficiency.

Conclusions: These findings suggest that genetically predicted differences in long-term vitamin D nutritional status do not causally affect susceptibility to and severity of COVID-19 infection, and that associations observed in previous studies may have been driven by confounding. These results do not exclude the possibility of low-magnitude causal effects, nor do they preclude potential causal effects of acute responses to therapeutic doses of vitamin D. Future directions include extension of this work to non-European ancestry populations, and high-risk populations, for example persons with comorbid disease. 
medRxiv preprint doi: https://doi.org/10.1101/2021.01.29.21250759; this version posted February 1, 2021. The copyright holder for this preprint (which was not certified by peer review) is the author/funder, who has granted medRxiv a license to display the preprint in perpetuity.

All rights reserved. No reuse allowed without permission.

\section{INTRODUCTION}

The COVID-19 pandemic has reached every corner of the globe and continues to spread.

59 With more than 100 million cases and 2.0 million deaths globally at time of writing, ${ }^{1}$

60 identification of risk factors for susceptibility to SARS-CoV-2 infection and severity of COVID-

6119 is critical. Vitamin D nutritional status is a promising modifiable risk factor, and higher

62 vitamin D is posited to reduce the risk of SARS-CoV-2 infection and the severity of the clinical

63 course of COVID-19. Hypothesized vitamin D effects are biologically plausible given prior

64 evidence that vitamin D upregulates innate and adaptive immunity to fight infection and reduce

65 inflammation, ${ }^{2}$ is associated with a reduced risk of respiratory disease mortality, ${ }^{3}$ and enhances

66 expression of ACE2, which is hypothesized to modulate the immune system response to SARS-

67 CoV-2 infection. ${ }^{4,5}$ A recent in vitro study showed that vitamin D reduces viral load of nasal

68 epithelial cells infected with SARS-CoV-2, ${ }^{6}$ and preliminary evidence from two small human

69 trials suggested that vitamin D supplementation may help improve the prognosis of COVID-19

70 in infected individuals. ${ }^{7,8}$

71 Ecological and observational studies lend further support to the hypothesis that lower

72 serum vitamin D concentrations are associated with both an increased risk of COVID-19 and an

73 increased severity of the infection. Early in the pandemic, the prevalence of COVID-19 in

74 European countries was negatively correlated with national averages for serum vitamin D

75 concentration. ${ }^{9}$ COVID-19 mortality rates were positively correlated with latitude, a proxy for

76 UV B exposure (higher latitude associates with lower UV B), which is required for synthesis of

77 vitamin D in the body. ${ }^{10,11}$ More recent studies report associations of lower pre-pandemic serum

78 vitamin D concentration or higher risk of vitamin D insufficiency with susceptibility to COVID-

7919 infection $^{12-14}$ and with severity of COVID-19 infection in hospitalized patients as indicated by

80 elevated biological markers of the cytokine storm, increased risk of intubation or use of 
medRxiv preprint doi: https://doi.org/10.1101/2021.01.29.21250759; this version posted February 1, 2021. The copyright holder for this preprint (which was not certified by peer review) is the author/funder, who has granted medRxiv a license to display the preprint in perpetuity.

All rights reserved. No reuse allowed without permission.

81 supplemental oxygen, ICU admission, and death. ${ }^{15-18}$ The mounting evidence from observational

82 studies and the known effects of vitamin D on the immune system contribute to speculation

83 about whether a simple and immediate intervention like vitamin D supplementation might be

84 effective in reducing risk of COVID-19 infection or severity, but sources of guidance for

85 clinicians and the public cite a lack of evidence for a causal association. ${ }^{19,20}$ Further evidence is

86 urgently needed.

The uncertainty about the causal association of vitamin D and COVID-19 arises because of the well-known association of serum vitamin D concentration with many known risk factors

89 for COVID-19, including age, sex, body mass index (BMI), and race/ethnicity. The largest

90 observational study of the UK Biobank data $(\mathrm{N}=348,598$ participants $)$ reported little to no

91 association of serum vitamin D with risk of COVID-19 infection in multivariate models adjusted

92 for covariates. ${ }^{21}$ In the absence of large, rigorous randomized trials, it is challenging to determine

93 whether other reported inverse associations of vitamin D and risk of COVID-19 are causal.

94 Given the high global prevalence of vitamin D insufficiency, estimating the true effect of vitamin

95 D on risk of COVID-19 infection and severity is important.

96 Mendelian randomization (MR), a study design to address causality, uses a form of

97 instrumental variable analysis to improve causal inference and to address the biases inherent in

98 observational studies. MR uses genetic variants that are associated with the exposure (i.e., serum

99 vitamin D) as instrumental variables, or genetic instruments, that represent the long-term usual

100 exposure. Following the laws of independent assortment, genetic variants are inherited from

101 parent to offspring in a random and independent manner. An individual's genotype therefore

102 mimics the lifelong randomization of individuals into groups with different long-term serum

103 vitamin D levels. Valid MR analysis depends on three key assumptions: (1) adequate strength 
medRxiv preprint doi: https://doi.org/10.1101/2021.01.29.21250759; this version posted February 1, 2021. The copyright holder for this preprint (which was not certified by peer review) is the author/funder, who has granted medRxiv a license to display the preprint in perpetuity.

All rights reserved. No reuse allowed without permission.

104 and validity of the genetic instruments (i.e., genetic variants that underlie vitamin D

105 metabolism), (2) independence of the genetic instruments from any confounders, and (3) absence

106 of direct effects of the genetic instruments on the outcome of interest (i.e., COVID-19 status).

107 MR addresses limitations in observational data including confounding, reverse causality, and

108 measurement error, and supports triangulation on the evidence for causality when randomized

109 trials are either impossible to conduct or currently unavailable. Genome-wide association (GWA)

110 studies of serum vitamin D levels identified genetic variants that are robustly associated with

111 serum vitamin D status in different populations and ancestries. ${ }^{22-28}$ Capitalizing on this finding,

112 researchers successfully applied MR to study associations of vitamin D with many clinical

113 outcomes, including diseases of immune system dysregulation and inflammation. ${ }^{29-45}$ We used

114 MR to investigate causality of the relationship of serum vitamin D status with the risk and

115 severity of COVID-19 infection.

\section{METHODS}

\section{Two-sample Mendelian Randomization with Multiple Instruments}

We estimated the effect of serum vitamin D levels on risk of COVID-19 infection and

119 severity with two-sample MR. ${ }^{46}$ The associations of the genetic instruments with the exposure(s)

120 and outcome(s) were estimated in separate, independent samples, then used to calculate the MR

121 estimate of the effect of serum vitamin D status on COVID-19. ${ }^{46}$ We used summary data from a

122 GWA study of serum vitamin D in the UK Biobank (sample 1) ${ }^{22}$ and genome-wide data for

123 COVID-19 patients versus comparison groups from the COVID-19 Host Genetics Initiative

124 (sample 2) (Figure 1). ${ }^{47}$ Because of overlap between the UK Biobank and the COVID-19 Host

125 Genetics Initiative samples, which may bias MR results toward effects estimated from traditional 
medRxiv preprint doi: https://doi.org/10.1101/2021.01.29.21250759; this version posted February 1, 2021. The copyright holder for this preprint (which was not certified by peer review) is the author/funder, who has granted medRxiv a license to display the preprint in perpetuity.

All rights reserved. No reuse allowed without permission.

126 observational studies, ${ }^{48}$ we replicated the analyses using summary GWAS data for serum vitamin

127 D from the SUNLIGHT Consortium. ${ }^{23}$ We also performed sensitivity analyses to evaluate prior

128 hypotheses about the direct effect of vitamin D deficiency or insufficiency on COVID-19

129 outcomes using summary data from a meta-analysis of associations of vitamin D SNPs with the

130 dichotomous outcome of vitamin D deficiency versus sufficiency. ${ }^{24}$

\section{Vitamin D Genetic Instrument(s)}

We constructed all genetic instruments for serum vitamin D levels based on independent

133 genetic loci associated with serum vitamin D levels at genome-wide significance $\left(\mathrm{p}<5 \times 10^{-8}\right)$.

134 For the primary analysis, we used a biologically plausible genetic instrument (instrument A)

135 consisting of SNPs in genetic loci that encode proteins in vitamin D transport and metabolism

136 (Supplemental Figure 1), including the vitamin D binding protein $(G C), 25 \mathrm{OH}$ hydroxylase

137 (CYP2R1), 7-dehydrocholesterol reductase (DHCR7), and 24-hydroxylase (CYP24A1). All SNPs

138 included in Instrument A were associated with serum vitamin D at genome-wide significance in

139 the UK Biobank and replicated in the SUNLIGHT Consortium. ${ }^{22,23}$

140 In secondary analyses, we expanded the genetic instrument to include additional genome-

141 wide significant SNPs in loci with no known relation to vitamin D metabolism (Figure 1). The

142 first expanded instrument (instrument B) included SNPs in two additional loci, Sec23 homolog A

$143(S E C 23 A)$ and amidohydrolase domain containing 1 (AMDHD1), that were associated with

144 serum vitamin D at genome-wide significance in both the UK Biobank and the SUNLIGHT

145 Consortium. The second expanded instrument (instrument C) included SNPs in 63 additional loci

146 associated with serum vitamin D at genome-wide significance in the UK Biobank (Supplemental

147 Table 1). 
medRxiv preprint doi: https://doi.org/10.1101/2021.01.29.21250759; this version posted February 1, 2021. The copyright holder for this preprint (which was not certified by peer review) is the author/funder, who has granted medRxiv a license to display the preprint in perpetuity.

All rights reserved. No reuse allowed without permission.

Finally, we constructed separate genetic instruments for risk of vitamin D deficiency and

149 insufficiency (defined as serum vitamin $\mathrm{D}<50 \mathrm{nmol} / \mathrm{L}$ and $<75 \mathrm{nmol} / \mathrm{L}$, respectively) based on

150 meta-analysis results of vitamin D SNP_risk of vitamin D deficiency/insufficiency associations

151 in the SUNLIGHT Consortium. ${ }^{24}$ The genome-wide significant SNPs contributing to the vitamin

152 D deficiency and insufficiency instruments were all in loci related to vitamin D metabolism,

153 including $G C, D H C R 7$, and $C Y P 2 R 1$.

\section{SNP_-Vitamin D Associations}

We extracted summary data, including beta-coefficients, standard errors, and effect

156 alleles and their frequencies for each SNP contributing to the genetic instruments. We primarily

157 used summary data from a UK Biobank GWAS of serum vitamin D in participants of "white

158 British" ancestry as defined by genotype principal component analysis $(\mathrm{N}=401,460)^{22}$ and

159 replicated the analyses using summary data from a SUNLIGHT Consortium meta-analysis

160 GWAS of serum vitamin D (31 European ancestry cohorts, $\mathrm{N}=79,366) .{ }^{23}$ For sensitivity

161 analyses, we used data from a SUNLIGHT Consortium meta-analysis of associations of vitamin

162 D SNPs with risk of vitamin D deficiency/insufficiency (four European ancestry cohorts, $\mathrm{N}=$

$16316,905) .^{24}$

164 Details of the UK Biobank and SUNLIGHT Consortia GWA studies of serum vitamin D

165 and the candidate SNP_-vitamin D deficiency/insufficiency meta-analysis are described

166 elsewhere. ${ }^{22-24}$ Briefly, in the UK Biobank GWAS, serum vitamin D data were log-transformed

167 and standardized to a mean of 0 and standard deviation of 1 , and SNP-vitamin D association

168 models were adjusted for age, sex, season of vitamin D measurement, vitamin D

169 supplementation, genotype batch, genotype array, and assessment center (as a proxy for latitude).

170 In the SUNLIGHT Consortium meta-analysis GWAS of serum vitamin D, serum vitamin D data 
medRxiv preprint doi: https://doi.org/10.1101/2021.01.29.21250759; this version posted February 1, 2021. The copyright holder for this preprint (which was not certified by peer review) is the author/funder, who has granted medRxiv a license to display the preprint in perpetuity.

All rights reserved. No reuse allowed without permission.

171 were log-transformed and SNP-vitamin D association models were adjusted for age, sex, BMI,

172 month of sample collection, cohort-specific variables such as geographical location and assay

173 batch, and genotype principal components. ${ }^{22}$ In the SUNLIGHT Consortium meta-analysis of

174 SNP_risk of vitamin D deficiency/insufficiency associations, models were adjusted for age, sex,

175 BMI, and season, and genomic control was applied to control for population stratification. ${ }^{24}$

\section{Vitamin D Instrument Strength}

We assessed the strength and validity of the genetic instruments for vitamin D by

178 calculating the F-statistic, ${ }^{49}$ according to the method described by Burgess and colleagues for

179 two-sample MR. ${ }^{48}$ First, we calculated the variance in vitamin D explained by each SNP $\left(\mathrm{R}^{2}\right.$ snp)

180 using the equation $\mathrm{R}_{\text {snp }}^{2}=2 \alpha^{2} \mathrm{MAF}(1-\mathrm{MAF})$, where $\alpha=\mathrm{SNP}-$ serum vitamin $\mathrm{D}$ association and

$181 \mathrm{MAF}=$ minor allele frequency. Next, we calculated the F-statistic for each of the instruments,

182 using the equation $\mathrm{F}=(\mathrm{N}-\mathrm{K}-1) / \mathrm{K} \times\left(\mathrm{R}_{\text {instrument }}^{2} /\left(1-\mathrm{R}^{2}\right.\right.$ instrument $)$, where $\mathrm{N}=$ sample size, $\mathrm{K}=$

183 number of SNPs contributing to the genetic instrument, and $\mathrm{R}_{\text {instrument }}^{2}=$ sum of $\mathrm{R}^{2}$ snp across

184 SNPs contributing to the instrument. We based all calculations on GWAS data from the UK

185 Biobank $^{22}$ and calculated the F-statistic for sample sizes of 10,000 and 1.3 million individuals,

186 the approximate minimum and maximum sample sizes for the COVID-19 outcomes. We

187 considered the MR standard of F-statistic >10 as an indicator of instrument strength. ${ }^{49}$

\section{SNP-COVID Associations}

We used genome-wide data for COVID-19 cases and comparison groups from the

190 COVID-19 Host Genetics Initiative, which is described elsewhere. ${ }^{47}$ Briefly, the initiative

191 comprises a global effort to study genetic contributions to variability in COVID-19 infection and

192 severity. Contributing studies performed genome-wide analyses for COVID-19 case and 
medRxiv preprint doi: https://doi.org/10.1101/2021.01.29.21250759; this version posted February 1, 2021. The copyright holder for this preprint (which was not certified by peer review) is the author/funder, who has granted medRxiv a license to display the preprint in perpetuity.

All rights reserved. No reuse allowed without permission.

193 comparison groups following an analysis plan developed by the initiative. Studies with multiple

194 ancestries performed stratified analyses, and all analyses were adjusted for sex, age, age, ${ }^{2}$ sex $\times$

195 age interaction, and genotype principal components. Results were summarized across studies and

196 ancestries by meta-analysis.

197 The publicly available summary results were downloaded from the COVID-19 Host

198 Genetics Initiative's fourth data freeze and meta-analysis (https://www.covid19hg.org/results/),

199 which were released on October 20, 2020. We considered the following five COVID-19 case

200 versus control comparisons, using definitions provided by the initiative: (1) any COVID-19

201 versus population controls, (2) hospitalized COVID-19 versus population controls, (3) very

202 severe respiratory confirmed COVID-19 versus population controls, (4) any COVID-19 versus

203 confirmed COVID-19 negative, and (5) hospitalized versus non-hospitalized COVID-19. For

204 each COVID-19 "case" versus comparison group, we extracted summary data, including beta-

205 coefficients, standard errors, effect alleles, and effect allele frequencies corresponding to the

206 SNPs included in the vitamin D genetic instruments. For SNPs that were not available in the

207 public data, we identified proxy SNPs based on linkage disequilibrium (LD), using the standard

208 MR threshold for LD proxies of $r^{2}>0.8 .^{50}$ All LD proxy SNPs were defined using 1000

209 Genomes European (CEU and GBR) sample data and identified through LDlink. ${ }^{51}$ Case and

210 comparison group definitions, sample sizes, and ancestry distributions for the different

211 comparisons are summarized in Table 1. Studies contributing to these analyses are listed in

212 Supplemental Table 1.

213 Summary data were available for mixed ancestry analyses for all outcomes. For the

214 outcomes of COVID-19 versus population controls and hospitalized COVID-19 versus

215 population controls, summary data from analyses limited to European ancestry participants were 
medRxiv preprint doi: https://doi.org/10.1101/2021.01.29.21250759; this version posted February 1, 2021. The copyright holder for this preprint (which was not certified by peer review) is the author/funder, who has granted medRxiv a license to display the preprint in perpetuity.

All rights reserved. No reuse allowed without permission.

216 also available. For these outcomes, we extracted summary data from both the mixed ancestry and

217 the European ancestry analyses for comparison and to address differences in ancestry

218 composition between vitamin D GWAS and COVID-19 Host Genetics Initiative sample

219 populations.

220 Stratification of SNP_-Vitamin D Associations by COVID-19 Risk Factors

221 Our study design assumes that the potential effect of vitamin D nutritional status on

222 susceptibility to and severity of COVID-19 infection is the same across different COVID-19 risk

223 categories, including ancestry, age, sex, BMI, and smoking status. MR analysis under this

224 assumption requires the genetic instruments for vitamin D to be robust across the COVID-19 risk

225 subgroups. To address this assumption, we conducted stratified analyses of the SNP-vitamin D

226 associations for all SNPs contributing to the genetic instruments using data from the UK

227 Biobank. UK Biobank Resource data—including serum vitamin D levels, vitamin D

228 supplementation, covariates and stratification variables, and imputed genotype dosages with

229 reference to Haplotype Reference Consortium and UK10K haplotype resource-were obtained

230 under Application Number 24603. The Institutional Review Board at RTI International approved

231 the UK Biobank data use and analysis.

The SNP-vitamin D associations were estimated stratified by sex (male vs. female), age

233 group (40-50 vs. 50-60 vs. $60-70)$, BMI category (18.5-25 vs. $25-30$ vs. $30-40$ vs. $>40$ ), and

234 smoking status (never vs. former vs. current smokers). Analyses were performed using the

235 GENESIS R/ Bioconductor package, ${ }^{52}$ separately for European ancestry $(\mathrm{N}=421,407)$ and

236 African ancestry $(\mathrm{N}=7,859)$ participants, as classified via analysis with STRUCTURE $^{53}$ in

237 comparison to the CEU, YRI, and CHB 1000 Genomes populations. ${ }^{54,55}$ Statistical models 
medRxiv preprint doi: https://doi.org/10.1101/2021.01.29.21250759; this version posted February 1, 2021. The copyright holder for this preprint (which was not certified by peer review) is the author/funder, who has granted medRxiv a license to display the preprint in perpetuity.

All rights reserved. No reuse allowed without permission.

238 resembled those described for SNP-vitamin D associations in UK Biobank, ${ }^{22}$ except that

239 genotype batch was not included as a covariate and vitamin D levels were not log-transformed.

\section{Statistical Analysis for Two-Sample MR}

We performed two-sample MR using the inverse variance weighted (IVW) method,

242 which assumes that pleiotropy is either non-existent or balanced (i.e., any associations of genetic

243 instrument SNPs with phenotypes other than vitamin D are randomly positive and negative such

244 that the mean pleiotropic effect is zero). ${ }^{56}$ We used the MR-Egger intercept test to check for

245 evidence of directional pleiotropy, and performed sensitivity analyses using the MR-Egger,

246 weighted-median and weighted-mode methods. ${ }^{57-59}$ The MR-Egger method relaxes the

247 assumption of no directional pleiotropy and corrects for pleiotropy-induced bias by allowing for

248 a nonzero intercept. ${ }^{56,57}$ The weighted-median method assumes that at least $50 \%$ of the weight of

249 the genetic instrument comes from nonpleiotropic SNPs and produces an unbiased estimate so

250 long as less than $50 \%$ of SNPs have pleiotropic effects. ${ }^{58}$ The weighted-mode method assumes

251 that the most common (modal) SNP-vitamin D effect is the true effect and therefore allows for

252 the inclusion of pleotropic SNPs without biasing the MR estimate. ${ }^{59}$ Where evidence of

253 directional pleiotropy existed (MR-Egger intercept test P-value <0.05) we prioritized the MR

254 estimates from the MR-Egger, mode-weighted, and median-weighted analyses, otherwise we

255 prioritized the estimates from the IVW method. Results for our primary analysis are presented as

256 odds ratios and 95\% confidence intervals (OR, 95\% CI) for COVID-19 case versus comparator

257 per standard deviation increase in log-transformed serum vitamin D. The threshold for statistical

258 significance was set at a P-value $<0.05$. All analyses were performed using $\mathrm{R}$ Studio version

259 1.2.1335 and the "TwoSampleMR" R package (https://github.com/MRCIEU/TwoSampleMR) $)^{50}$. 
medRxiv preprint doi: https://doi.org/10.1101/2021.01.29.21250759; this version posted February 1, 2021. The copyright holder for this preprint (which was not certified by peer review) is the author/funder, who has granted medRxiv a license to display the preprint in perpetuity.

All rights reserved. No reuse allowed without permission.

We estimated potential bias under the null due to sample overlap between the UK

261 Biobank vitamin D GWAS and the COVID-19 Host Genetics Initiative using estimates of the

262 vitamin D-COVID-19 associations from observational studies, the percentage of sample overlap,

263 and the relative bias (reciprocal of the F-statistic), as previously described. ${ }^{48}$ We compared SNP-

264 vitamin D associations stratified by sex, age group, BMI category, and smoking status with

265 Pearson's correlation coefficients.

266 We calculated the minimum odds ratio detectable at $80 \%$ power for each COVID-19

267 outcome using the "mRnd" tool (https://shiny.cnsgenomics.com/mRnd/). ${ }^{60}$ Based on heritability

268 estimates from the UK Biobank and SUNLIGHT Consortium vitamin D GWA studies, ${ }^{23,61}$ we

269 assumed the genetic instruments accounted for $3 \%$ of the variance in serum vitamin D for all

270 power calculations.

271 Patient and Public Involvement

272 We used publicly available data from several consortia including the UK Biobank, the

273 SUNLIGHT Consortium and the COVID-19 Host Genetics Initiative in this study. These

274 consortia were not involved in any stage of the design and conduct of this research, nor were

275 they asked to advise on interpretation or writing up of results. No patients were involved in any

276 stage of the research process. There are no plans to disseminate the results of the research to

277 study participants or the relevant patient community.

278 RESULTS

279 Genetic Instruments for Vitamin D

Characteristics of the genetic instruments for serum vitamin D, including contributing

281 SNPs, SNP-vitamin D associations in the UK Biobank, and F-statistics, indicate that instruments 
medRxiv preprint doi: https://doi.org/10.1101/2021.01.29.21250759; this version posted February 1, 2021. The copyright holder for this preprint (which was not certified by peer review) is the author/funder, who has granted medRxiv a license to display the preprint in perpetuity.

All rights reserved. No reuse allowed without permission.

A and B clearly exceed the MR standard for instrument strength of F-statistic $>10$ across the range of COVID-19 outcome sample sizes (Table 2, Supplemental Table 2). The F-statistics for participants and 6,915, 4,746, and 600 for the maximum sample size of 1.3 million participants. Instrument A, which was limited to SNPs in loci related to vitamin D metabolism

287 (Supplementary Figure 1), had the largest F-statistics across all sample sizes, reflecting the 288 strength of the SNP-vitamin D associations for the SNPs in loci related to the vitamin D 289 metabolic pathway.

\section{COVID-19 Case-Comparison Groups and Power Calculations}

We considered multiple case definitions, sample sizes, and ancestral compositions for the COVID-19 case-control comparisons in our analysis (Table 1). Sample sizes across the analyses

293 ranged from just over 10,000 (for hospitalized COVID-19 vs. non-hospitalized COVID-19) to

294 over 1.3 million (for COVID-19 vs. population). The majority (>75\%) of participants were of

295 European ancestry. Non-European ancestry participants made up a much smaller fraction of the 296 total sample.

297 Based on the sample sizes across the COVID-19 case-control comparisons, and assuming 298 our genetic instruments explained $3 \%$ of the variance in serum vitamin D, we calculated that this 299 study had $80 \%$ power to detect moderate effect sizes comparable to those seen in observational

300 studies. The minimum detectable ORs for a standard deviation increase in serum vitamin D

301 ranged from 0.66 (hospitalized COVID-19 vs. non-hospitalized COVID-19) to 0.86 (COVID-19

302 vs. population; Supplemental Table 3). 
medRxiv preprint doi: https://doi.org/10.1101/2021.01.29.21250759; this version posted February 1, 2021. The copyright holder for this preprint (which was not certified by peer review) is the author/funder, who has granted medRxiv a license to display the preprint in perpetuity.

All rights reserved. No reuse allowed without permission.

\section{MR Estimates for Serum Vitamin D Effect on COVID-19 Outcomes}

MR estimates (odds ratios and $95 \%$ confidence intervals) for the effect of genetically

305 predicted serum vitamin D on risk of COVID-19 outcomes, calculated separately for instruments

306 A, B, and C, are shown in Figure 2 and Table 3. MR scatter plots and forest plots further

307 illustrating these results are shown in Supplementary Figure 2. MR-Egger intercept tests for

308 pleiotropy were not statistically significant (MR-Egger intercept p-values $>0.1$ ) for all

309 instruments and all outcomes (Table 3). Thus, we prioritized the MR estimates from the IVW

310 analyses and found little to no evidence for an effect of vitamin D on risk of any COVID-19

311 outcome considered. For instrument A, using SNPs in loci related to vitamin D metabolism, the

312 odds ratio for a standard deviation increase in serum vitamin D was 1.04 (95\% confidence

313 interval 0.92 to 1.18$)$ for any COVID-19 infection versus population controls, 1.05 (0.84-1.31)

314 for hospitalized COVID-19 versus population controls, 0.96 (0.64 to 1.43) for severe respiratory

315 COVID-19 versus population controls, 1.15 (0.99 to 1.35) for COVID-19 positive versus

316 COVID-19 negative, and 1.44 (0.75 to 2.78) for hospitalized COVID-19 versus non-hospitalized

317 COVID-19 (p-values >0.1 for all comparisons). Results were similar for instruments B and C.

318 Results of MR analyses limited to European ancestry participants, which we were able to

319 perform for the outcomes of COVID-19 versus population and hospitalized COVID-19 versus

320 population, were also non-significant (Supplementary Figure 3).

$321 \quad$ For all outcomes, the MR-Egger intercept test showed little to no evidence of pleiotropy

322 (Table 3). Nevertheless, we performed sensitivity analysis to explore possible pleiotropy using

323 the MR-Egger, weighted-median, and weighted-mode MR methods, and this analysis showed a

324 direct association of serum vitamin D with risk of hospitalized COVID-19 versus non-

325 hospitalized COVID-19 (Supplemental Figure 4). For this outcome, MR estimates from the MR- 
medRxiv preprint doi: https://doi.org/10.1101/2021.01.29.21250759; this version posted February 1, 2021. The copyright holder for this preprint (which was not certified by peer review) is the author/funder, who has granted medRxiv a license to display the preprint in perpetuity.

All rights reserved. No reuse allowed without permission.

326 Egger and mode-weighted analyses found that chronically higher vitamin D levels increase the

327 odds of hospitalization in COVID-19-infected participants (OR [95\% CI] for instrument A: 1.83

$328[1.12,2.97]$ for mode-weighted MR and 3.69 [1.53, 8.93] for MR-Egger). MR estimates from the

329 MR-Egger, mode- and median-weighted MR analyses were non-significant for all other

330 outcomes, consistent with results from the IVW analysis.

331 Estimations of bias because of participant overlap between the UK Biobank and the

332 COVID-19 Host Genetics Initiative were negligible. For the outcome with maximum participant

333 overlap (58\% for severe respiratory COVID-19 vs. population), we estimated the bias for

334 instruments $\mathrm{A}, \mathrm{B}$, and $\mathrm{C}$ to be $0.1 \%, 0.2 \%$, and $1.0 \%$ respectively. We confirmed the negligible

335 effect of participant overlap in our study by repeating the analyses using summary data for

336 GWAS significant SNP-vitamin D associations from the SUNLIGHT consortium in place of UK

337 Biobank data (Supplementary Table 4). Results using the SUNLIGHT Consortium data were

338 consistent with results using the UK Biobank data; there was no evidence of pleiotropy for any

339 outcome (MR-Egger intercept p-value >0.1), and IVW MR estimates for the effect of genetically

340 predicted serum vitamin D on risk of COVID-19 outcomes were similar in magnitude and

341 direction and were not statistically significant (Supplementary Table 4).

\section{MR Estimates for Vitamin D Deficiency/Insufficiency and COVID-19 Outcomes}

343 A further sensitivity analysis evaluated the effect of genetically predicted vitamin D

344 deficiency and insufficiency on COVID-19 outcomes (Table 3, Figure 4). MR-Egger intercept

345 tests for pleiotropy were all non-significant ( $\mathrm{p}$-value $>0.1$ ), and the IVW MR estimates did not

346 support an effect of long-term vitamin D deficiency or insufficiency on the risk of any of the

347 COVID-19 outcomes evaluated (Table 3, Figure 4). 
medRxiv preprint doi: https://doi.org/10.1101/2021.01.29.21250759; this version posted February 1, 2021. The copyright holder for this preprint (which was not certified by peer review) is the author/funder, who has granted medRxiv a license to display the preprint in perpetuity.

All rights reserved. No reuse allowed without permission.

\section{Covariate Effects on SNP-Vitamin D Associations}

Stratified analyses of SNP-vitamin D associations evaluated the validity of the genetic

350 instruments across known COVID-19 risk factors, including ancestry, age, sex, BMI, and

351 smoking status. Correlations of age-, sex-, BMI-, and smoking status-specific SNP-vitamin D

352 associations are shown separately for European $(\mathrm{N}=421,407)$ and African $(\mathrm{N}=7,859)$ ancestry

353 participants in Supplemental Figure 5. For European ancestry participants, subgroup-specific

354 SNP-vitamin D associations were strongly correlated across age, sex, BMI category, and

355 smoking status (Pearson's correlation coefficients ranging from 0.90 to 0.99), supporting the use

356 of the instrument in the general European ancestry population. For African ancestry participants,

357 the correlations among subgroup-specific SNP-vitamin D associations were less clear (Pearson's

358 correlation coefficients ranged from -0.95 to 0.72 ), suggesting that optimization of the genetic

359 instruments for the African ancestry population may be necessary. Given the small sample sizes

360 in the African ancestry subgroups, further research is needed to validate the instruments and their

361 use in African and other non-European Ancestry populations.

\section{DISCUSSION}

363 We used summary data from genome-wide analysis in the UK Biobank, SUNLIGHT

364 Consortium, and COVID-19 Host Genetics Initiative to conduct the first MR study of serum

365 vitamin D and COVID-19 outcomes. Although our study was powered to detect effects

366 comparable to those seen in observational studies of vitamin D and COVID-19, we found little to

367 no evidence of an effect of genetically predicted serum vitamin D levels on COVID-19

368 outcomes, including risk of COVID-19 infection, severe respiratory infection, and

369 hospitalization. Our results were robust to multiple genetic instruments for vitamin D and were

370 replicated using SNP-vitamin D association data from two independent samples. Results from 
medRxiv preprint doi: https://doi.org/10.1101/2021.01.29.21250759; this version posted February 1, 2021. The copyright holder for this preprint (which was not certified by peer review) is the author/funder, who has granted medRxiv a license to display the preprint in perpetuity.

All rights reserved. No reuse allowed without permission.

371 sensitivity analyses evaluating the effect of genetically predicted vitamin D deficiency or

372 insufficiency on risk of COVID-19 outcomes were similarly null. In summary, our results

373 suggest that long-term usual vitamin D nutritional status does not have a causal effect on

374 susceptibility to COVID-19 infection and its severity.

375 Our results are consistent with findings from the largest observational study to date of

376 serum vitamin D and COVID-19 infection, ${ }^{21}$ which used UK Biobank data on approximately

377350,000 White, Black, and South Asian participants, and found associations of pre-pandemic

378 vitamin D levels with COVID-19 infection in univariate models, but not in models adjusting for

379 confounding by known COVID-19 risk factors, including age, sex, race/ethnicity, BMI,

380 socioeconomic status, smoking status, diabetes, blood pressure, chronic illness, and disability.

381 We used the MR approach as an alternative way to address potential confounding. We

382 instrumented long-term serum vitamin D status with genetic variants that are unlikely to have

383 direct associations with known risk factors for COVID-19 infection. Specifically, the genetic

384 instrument for our primary analysis (instrument A) was limited to SNPs in loci with functional

385 links to serum vitamin D, including $G C, D H C R 7, C Y P 2 R 1$, and $C Y P 24 A 1$. With this approach,

386 we saw no evidence for an effect of genetically predicted (i.e., unconfounded) variation in serum

387 vitamin D on risk and severity of COVID-19 infection.

388 These results are contrary to findings from several smaller observational studies showing

389 an association of lower vitamin D levels with higher risk of testing positive for COVID-19 in the

390 general population ${ }^{12-14}$ and higher risk of COVID-19 related hospitalization, ICU admission,

391 intubation and death among infected individuals. ${ }^{15-18}$ However, these studies were inconsistent in

392 the covariates included in statistical models, and in several studies estimates of vitamin D

393 associations with susceptibility to and severity of COVID-19 infection were attenuated with 
medRxiv preprint doi: https://doi.org/10.1101/2021.01.29.21250759; this version posted February 1, 2021. The copyright holder for this preprint (which was not certified by peer review) is the author/funder, who has granted medRxiv a license to display the preprint in perpetuity.

All rights reserved. No reuse allowed without permission.

394 covariate adjustment, suggesting the observed effects could be the result of residual confounding.

395 Additionally, many of these studies were case-control or cross-sectional studies, making it

396 difficult to rule out the possibility of reverse causality (i.e., that COVID-19 infection or its

397 symptoms could lead to lowering of serum vitamin D). The MR approach addresses key

398 limitations of these studies, including confounding and reverse causality, and is recognized as a

399 method for improving causal inference in epidemiology.

$400 \quad$ This study has many strengths. We used summary data from the largest GWA studies of

401 serum vitamin D to maximize the strength and validity of the genetic instruments for vitamin D

402 and leveraged publicly available data on nearly 1.4 million participants, including 17,965

403 COVID-19 cases, from 38 study cohorts in the COVID-19 Host Genetics Initiative. We

404 addressed potential pleiotropy of the genetic instruments, which if present would limit the

405 interpretation of the MR results, by comparing results across the biologically plausible and

406 expanded instruments, testing for evidence of pleiotropy with the MR-Egger intercept test, and

407 performing sensitivity analysis with alternative MR methods that address pleiotropy. We

408 explored potential threshold effects using genetic instruments for vitamin D deficiency and

409 insufficiency. Our findings were robust across all exploration, and, in triangulation with results

410 of the largest to date observational study of vitamin D and COVID-19, the findings help to

411 clarify the nature of the association of vitamin D with COVID-19 outcomes.

412 As in any MR study, the valid interpretation of our results rests on the MR assumptions

413 of adequate strength of the genetic instruments for vitamin D and absence of direct effects of the

414 instruments on COVID-19 outcomes and potential confounders (i.e., pleiotropy). Our

415 instruments easily met the MR standard for instrument strength (F-statistic $>10$ ) and we found no

416 evidence of pleiotropy from the MR-Egger intercept test. Our results were consistent across the 
medRxiv preprint doi: https://doi.org/10.1101/2021.01.29.21250759; this version posted February 1, 2021. The copyright holder for this preprint (which was not certified by peer review) is the author/funder, who has granted medRxiv a license to display the preprint in perpetuity.

All rights reserved. No reuse allowed without permission.

417 biologically plausible and expanded genetic instruments and largely similar in sensitivity

418 analysis using MR methods designed to address pleiotropy. While the findings in our study are

419 unlikely to be biased by pleiotropy, exhaustive tests for pleiotropy are challenging, making the

420 MR assumptions difficult to fully verify.

421 We used a two-sample MR approach, using estimates of associations of the genetic

422 instruments with vitamin D and with COVID-19 outcomes from two separate samples. This

423 approach maximizes sample size and reduces the likelihood of bias toward estimates from

424 observational studies ${ }^{46}$ but requires that the two samples are drawn from similar populations. In

425 our study, the summary data for associations of the genetic instruments with vitamin D were

426 from analyses in European ancestry participants, while the data for associations of the genetic

427 instruments with COVID-19 outcomes were from analyses including up to $25 \%$ non-European

428 ancestry participants. Repeating the analysis with a subgroup of European-only participants for

429 two outcomes, COVID-19 versus population controls and hospitalized COVID-19 versus

430 population controls, indicated minimal impact of ancestral differences on MR estimates.

431 However, ancestry-specific data were not available for COVID-19 outcomes with larger

432 proportions of non-European ancestry participants, and the impact of ancestral differences could

433 not be fully explored. In sensitivity analyses using alternative MR methods that assume some

434 pleiotropy, findings indicated an association of higher vitamin D levels with higher risk of

435 hospitalization among COVID-19-infected individuals, the outcome with the highest proportion

436 of non-European ancestry participants. This finding could be driven by racial/ethnic disparities in

437 access to health care (i.e., hospitalized COVID-19 individuals may be more likely of European

438 ancestry and therefore have higher vitamin D status). We also found evidence for racial

439 differences in risk-factor stratified SNP-vitamin D associations. Our results suggest that SNP- 
medRxiv preprint doi: https://doi.org/10.1101/2021.01.29.21250759; this version posted February 1, 2021. The copyright holder for this preprint (which was not certified by peer review) is the author/funder, who has granted medRxiv a license to display the preprint in perpetuity.

All rights reserved. No reuse allowed without permission.

440 vitamin D associations are strongly correlated across sex, age, BMI, and smoking subgroups for

441 individuals of European ancestry, but not for individuals of African ancestry, although because

442 of small sample sizes for the African ancestry subgroups we are unable to draw firm conclusions.

443 Further research using data from ancestry-specific GWA studies of vitamin D and COVID-19

444 outcomes is warranted to further investigate the impact of race/ethnicity on the vitamin D-

445 COVID-19 relationship.

446 This study was not designed to evaluate the effect of acute changes in vitamin D status

447 (i.e., from supplementation) on prevention or treatment of COVID-19. One randomized trial and

448 one quasi-experimental trial have provided evidence for a positive effect of vitamin D

449 supplementation around time of diagnosis on COVID-19 prognosis in infected individuals. The

450 doses of vitamin D administered in these studies could result in an acute change in the

451 availability of vitamin D, which may support the immune system's response to the virus,

452 mitigate acute lung injury, and contribute to improved prognosis. Our results, which pertain to

453 long-term vitamin D status, do not preclude the possibility that therapeutic doses of vitamin D

454 may be effective in preventing or treating COVID-19 infection. Larger randomized trials using

455 diverse sample populations are needed to investigate the potential use of therapeutic doses of

456 vitamin D supplementation for COVID-19 prevention and treatment.

457 In conclusion, we used two-sample MR to study the associations of vitamin D with

458 COVID-19 outcomes to address limitations of existing observational studies, including

459 confounding and reverse causality. We found no evidence for an effect of genetically predicted

460 variation in serum vitamin D on risk or severity of COVID-19 infection. Our findings suggest

461 that chronic differences in serum vitamin D do not have a causal effect on susceptibility to

462 COVID-19 infection or severity of COVID-19 among those infected, and that associations 
medRxiv preprint doi: https://doi.org/10.1101/2021.01.29.21250759; this version posted February 1, 2021. The copyright holder for this preprint (which was not certified by peer review) is the author/funder, who has granted medRxiv a license to display the preprint in perpetuity.

All rights reserved. No reuse allowed without permission.

463 observed in previous studies may have been driven by confounding. Future directions of this

464 work include extension of the MR approach to non-European ancestry populations, and

465 investigation of potential modification of genetically predicted vitamin D effects on COVID-19

466 risk and severity by COVID-19 risk factors, including race/ethnicity, age, sex, and BMI.

467 Randomized trials are needed to inform the question of whether acute changes in vitamin D

468 levels (i.e., from supplementation) are efficacious in COVID-19 prevention and treatment across

469 diverse populations.

470

471 SUMMARY BOX

472 What is already known on this topic

473 - Observational studies report that lower vitamin D levels are associated with increased risk

474 and severity of COVID-19

475 - Known risk factors for COVID-19 are associated with lower vitamin D levels in blood

476 - It is unknown whether observed associations of vitamin D and COVID-19 are causal

\section{What this study adds}

478 - This study found no evidence for associations of genetically predicted long-term vitamin D

479 levels with risk and severity of COVID-19 infection

480 - The findings do not support a causal effect of long-term usual vitamin D nutritional status on

$481 \quad$ COVID-19 infection and its severity

482 - These findings have implications for the potential effectiveness of low level vitamin D

483 supplementation as a strategy for COVID-19 prevention and treatment, but do not address the

484 therapeutic use of vitamin $\mathrm{D}$ in acute disease 
medRxiv preprint doi: https://doi.org/10.1101/2021.01.29.21250759; this version posted February 1, 2021. The copyright holder for this preprint (which was not certified by peer review) is the author/funder, who has granted medRxiv a license to display the preprint in perpetuity.

All rights reserved. No reuse allowed without permission.

\section{FOOTNOTES}

487 Contributor and Guarantor Confirmation: The study was designed and conceived by BKP,

488 PAC and AGC. The MR analyses were performed by BKP in close consultation with PAC. The

489 follow-up stratified analyses of SNP_-vitamin D associations were performed by NG. The

490 manuscript was drafted by BKP and PAC, and edited with input from AGC, DBH and NG. All

491 authors reviewed and contributed to the discussion of findings and the crafting of the manuscript

492 and gave final approval to the version submitted for publication. PAC is the guarantor.

493 Funding: BKP was supported by the National Institutes of Health under award T32-DK007158.

494 ACG was supported by the National Institutes of Health under award R01-HG006849. NG, DBH

495 and PAC were partially supported by the National Institutes of Health under award R01-

496 HL149352. The study content is solely the responsibility of the authors and does not necessarily

497 represent the official views of the funders. The funders had no role in the study design, data

498 collection, analysis, interpretation, or writing, nor in the decision to submit the article for

499 publication.

500 Competing interests: All authors have completed the ICMJE uniform disclosure form at

501 www.icmje.org/coi_disclosure.pdf and declare: no support from any organization for the

502 submitted work; BKP was supported by the National Institutes of Health during the conduct of

503 the study, AGC, DBH and PAC report receiving grants from the National Institutes of Health

504 during the conduct of the study; no other relationships or activities that could appear to have

505 influenced the submitted work.

506 Ethics approval: The main analysis conducted in this study used publicly available summary

507 data and did not require ethical approval. The use of UK Biobank data for the stratified analysis 
medRxiv preprint doi: https://doi.org/10.1101/2021.01.29.21250759; this version posted February 1, 2021. The copyright holder for this preprint (which was not certified by peer review) is the author/funder, who has granted medRxiv a license to display the preprint in perpetuity.

All rights reserved. No reuse allowed without permission.

508 of SNP — vitamin D associations by COVID-19 risk factors was approved by the Institutional

509 Review Board at RTI International.

510 Data sharing: All data used for this analysis are publicly available. Code implementing the

511 MR analysis is available upon request from the corresponding author.

512 Transparency: PAC is the corresponding author and guarantor for this paper and affirms that

513 the manuscript is an honest, accurate, and transparent account of the study being reported; that

514 no important aspects of the study have been omitted; and that any discrepancies from the study

515 as originally planned have been explained.

516 Copyright: The Corresponding Author has the right to grant on behalf of all authors and does

517 grant on behalf of all authors, a worldwide licence to the Publishers and its licensees in

518 perpetuity, in all forms, formats and media (whether known now or created in the future), to i)

519 publish, reproduce, distribute, display and store the Contribution, ii) translate the Contribution

520 into other languages, create adaptations, reprints, include within collections and create

521 summaries, extracts and/or, abstracts of the Contribution, iii) create any other derivative work(s)

522 based on the Contribution, iv) to exploit all subsidiary rights in the Contribution, v) the inclusion

523 of electronic links from the Contribution to third party material where-ever it may be located;

524 and, vi) licence any third party to do any or all of the above.

525

526

527

528 
medRxiv preprint doi: https://doi.org/10.1101/2021.01.29.21250759; this version posted February 1, 2021. The copyright holder for this preprint (which was not certified by peer review) is the author/funder, who has granted medRxiv a license to display the preprint in perpetuity.

\section{REFERENCES}

530 1. Home. Johns Hopkins Coronavirus Resource Center https://coronavirus.jhu.edu/.

531 2. Guillot, X., Semerano, L., Saidenberg-Kermanac'h, N., Falgarone, G. \& Boissier, M.-C.

$532 \quad$ Vitamin D and inflammation. Joint Bone Spine 77, 552-557 (2010).

533 3. Brenner, H., Holleczek, B. \& Schöttker, B. Vitamin D Insufficiency and Deficiency and Mortality from Respiratory Diseases in a Cohort of Older Adults: Potential for Limiting the Death Toll during and beyond the COVID-19 Pandemic? Nutrients 12, (2020).

4. Cui, C. et al. Vitamin D receptor activation regulates microglia polarization and oxidative stress in spontaneously hypertensive rats and angiotensin II-exposed microglial cells: Role of renin-angiotensin system. Redox Biol. 26, 101295 (2019).

5. Kai, H. \& Kai, M. Interactions of coronaviruses with ACE2, angiotensin II, and RAS inhibitors-lessons from available evidence and insights into COVID-19. Hypertens. Res. 1-7 (2020) doi:10.1038/s41440-020-0455-8.

6. Mok, C. K. et al. Calcitriol, the active form of vitamin D, is a promising candidate for COVID-19 prophylaxis. bioRxiv 2020.06.21.162396 (2020) doi:10.1101/2020.06.21.162396.

7. Entrenas Castillo, M. et al. Effect of calcifediol treatment and best available therapy versus best available therapy on intensive care unit admission and mortality among patients hospitalized for COVID-19: A pilot randomized clinical study. J. Steroid Biochem. Mol. Biol. 203, 105751 (2020).

8. Annweiler, C. et al. Vitamin D and survival in COVID-19 patients: A quasi-experimental study. J. Steroid Biochem. Mol. Biol. 204, 105771 (2020).

9. Ilie, P. C., Stefanescu, S. \& Smith, L. The role of vitamin D in the prevention of coronavirus disease 2019 infection and mortality. Aging Clin. Exp. Res. 32, 1195-1198 (2020).

10. Whittemore, P. B. COVID-19 fatalities, latitude, sunlight, and vitamin D. Am. J. Infect. Control 48, 1042-1044 (2020).

11. Kohlmeier, M. Avoidance of vitamin D deficiency to slow the COVID-19 pandemic. BMJ Nutr. Prev. Health bmjnph-2020-000096 (2020) doi:10.1136/bmjnph-2020-000096.

12. Kaufman, H. W., Niles, J. K., Kroll, M. H., Bi, C. \& Holick, M. F. SARS-CoV-2 positivity

14. D'Avolio, A. et al. 25-Hydroxyvitamin D Concentrations Are Lower in Patients with Positive PCR for SARS-CoV-2. Nutrients 12, 1359 (2020). 
medRxiv preprint doi: https://doi.org/10.1101/2021.01.29.21250759; this version posted February 1, 2021. The copyright holder for this preprint (which was not certified by peer review) is the author/funder, who has granted medRxiv a license to display the preprint in perpetuity. All rights reserved. No reuse allowed without permission.

15. Ye, K. et al. Does Serum Vitamin D Level Affect COVID-19 Infection and Its Severity?-A Case-Control Study. J. Am. Coll. Nutr. (2020) doi:10.1080/07315724.2020.1826005.

16. Maghbooli, Z. et al. Vitamin D sufficiency, a serum 25 -hydroxyvitamin D at least $30 \mathrm{ng} / \mathrm{mL}$ reduced risk for adverse clinical outcomes in patients with COVID-19 infection. PloS One 15, e0239799 (2020).

17. Macaya, F. et al. Interaction between age and vitamin D deficiency in severe COVID-19 infection. Nutr. Hosp. 37, 1039-1042 (2020).

18. Baktash, V. et al. Vitamin D status and outcomes for hospitalised older patients with COVID-19. Postgrad. Med. J. (2020) doi:10.1136/postgradmedj-2020-138712.

19. COVID-19 Treatment Guidelines Panel. Coronavirus Disease 2019 (COVID-19) Treatment Guidelines. COVID-19 Treatment Guidelines https://www.covid19treatmentguidelines.nih.gov/adjunctive-therapy/vitamin-d/.

20. Williams, C. \& Gingery, J. G. Joint guidance on vitamin D in the era of COVID-19. Endocrine Society https://www.endocrine.org/news-and-advocacy/news-room/2020/jointguidance-on-vitamin-d (2020).

21. Hastie, C. E. et al. Vitamin D concentrations and COVID-19 infection in UK Biobank. Diabetes Metab. Syndr. Clin. Res. Rev. 14, 561-565 (2020).

22. Manousaki, D. et al. Genome-wide Association Study for Vitamin D Levels Reveals 69 Independent Loci. Am. J. Hum. Genet. 106, 327-337 (2020).

23. Jiang, X. et al. Genome-wide association study in 79,366 European-ancestry individuals informs the genetic architecture of 25-hydroxyvitamin D levels. Nat. Commun. 9, 260 (2018).

24. Wang, T. J. et al. Common genetic determinants of vitamin D insufficiency: a genome-wide association study. Lancet 376, 180-188 (2010).

25. Ahn, J. et al. Genome-wide association study of circulating vitamin D levels. Hum. Mol. Genet. 19, 2739-2745 (2010).

26. Hong, J. et al. Transethnic Evaluation Identifies Low-Frequency Loci Associated With 25Hydroxyvitamin D Concentrations. J. Clin. Endocrinol. Metab. 103, 1380-1392 (2018).

27. Arabi, A. et al. CYP2R1 polymorphisms are important modulators of circulating 25hydroxyvitamin D levels in elderly females with vitamin insufficiency, but not of the response to vitamin D supplementation. Osteoporos. Int. J. Establ. Result Coop. Eur. Found. Osteoporos. Natl. Osteoporos. Found. USA 28, 279-290 (2017).

28. Jones, P. et al. Distribution of variants in multiple vitamin D-related loci (DHCR7/NADSYN1, GC, CYP2R1, CYP11A1, CYP24A1, VDR, RXR $\alpha$ and RXR $\gamma$ ) vary 
medRxiv preprint doi: https://doi.org/10.1101/2021.01.29.21250759; this version posted February 1, 2021. The copyright holder for this preprint (which was not certified by peer review) is the author/funder, who has granted medRxiv a license to display the preprint in perpetuity.

All rights reserved. No reuse allowed without permission.

between European, East-Asian and Sub-Saharan African-ancestry populations. Genes Nutr. 15, 5 (2020).

29. Liefaard, M. C. et al. Vitamin D and C-Reactive Protein: A Mendelian Randomization Study. PloS One 10, e0131740 (2015).

30. Afzal, S., Brondum-Jacobsen, P., Bojesen, S. E. \& Nordestgaard, B. G. Genetically low vitamin D concentrations and increased mortality: Mendelian randomisation analysis in three large cohorts. BMJ 349, g6330 (2014).

31. Brondum-Jacobsen, P., Benn, M., Afzal, S. \& Nordestgaard, B. G. No evidence that genetically reduced 25-hydroxyvitamin D is associated with increased risk of ischaemic heart disease or myocardial infarction: a Mendelian randomization study. Int. J. Epidemiol.

32. Bae, S.-C. \& Lee, Y. H. Vitamin D level and risk of systemic lupus erythematosus and rheumatoid arthritis: a Mendelian randomization. Clin. Rheumatol. 37, 2415-2421 (2018).

33. Hysinger, E. B. et al. Mendelian randomization analysis demonstrates that low vitamin D is

34. Manousaki, D., Mokry, L. E., Ross, S., Goltzman, D. \& Richards, J. B. Mendelian Randomization Studies Do Not Support a Role for Vitamin D in Coronary Artery Disease. Circ. Cardiovasc. Genet. 9, 349-356 (2016).

35. Manousaki, D. et al. Vitamin D levels and susceptibility to asthma, elevated immunoglobulin E levels, and atopic dermatitis: A Mendelian randomization study. PLoS Med. 14, e1002294 (2017).

36. Mao, Y., Zhan, Y. \& Huang, Y. Vitamin D and asthma: A Mendelian randomization study. Ann. Allergy Asthma Immunol. Off. Publ. Am. Coll. Allergy Asthma Immunol. 119, 95-97.e1 (2017).

37. Mokry, L. E. et al. Genetically decreased vitamin D and risk of Alzheimer disease. Neurology 87, 2567-2574 (2016).

38. Ong, J.-S. et al. Association of vitamin D levels and risk of ovarian cancer: a Mendelian randomization study. Int. J. Epidemiol. 45, 1619-1630 (2016).

39. Skaaby, T. et al. Vitamin D status, filaggrin genotype, and cardiovascular risk factors: a Mendelian randomization approach. PloS One 8, e57647 (2013).

627 40. Taylor, A. E. et al. Investigating causality in the association between 25(OH)D and 59, 793-797 (2013). 
medRxiv preprint doi: https://doi.org/10.1101/2021.01.29.21250759; this version posted February 1, 2021. The copyright holder for this preprint (which was not certified by peer review) is the author/funder, who has granted medRxiv a license to display the preprint in perpetuity.

All rights reserved. No reuse allowed without permission.

42. Viatte, S. et al. The role of genetic polymorphisms regulating vitamin D levels in rheumatoid arthritis outcome: a Mendelian randomisation approach. Ann. Rheum. Dis. 73, 1430-1433 (2014).

43. Vimaleswaran, K. S. et al. Causal relationship between obesity and vitamin D status: bidirectional Mendelian randomization analysis of multiple cohorts. PLoS Med. 10, e1001383 (2013).

44. Vimaleswaran, K. S. et al. Association of vitamin D status with arterial blood pressure and hypertension risk: a mendelian randomisation study. Lancet Diabetes Endocrinol. 2, 719729 (2014).

45. Ye, Z. et al. Association between circulating 25-hydroxyvitamin D and incident type 2 diabetes: a mendelian randomisation study. Lancet Diabetes Endocrinol. 3, 35-42 (2015).

46. Burgess, S., Butterworth, A. \& Thompson, S. G. Mendelian Randomization Analysis With Multiple Genetic Variants Using Summarized Data. Genet. Epidemiol. 37, 658-665 (2013).

47. The COVID-19 Host Genetics Initiative, a global initiative to elucidate the role of host genetic factors in susceptibility and severity of the SARS-CoV-2 virus pandemic. Eur. J. Hum. Genet. 1-4 (2020) doi:10.1038/s41431-020-0636-6.

48. Burgess, S., Davies, N. M. \& Thompson, S. G. Bias due to participant overlap in two $\square$ sample Mendelian randomization. Genet. Epidemiol. 40, 597-608 (2016).

49. Burgess, S., Thompson, S. G. \& Collaboration, C. C. G. Avoiding bias from weak instruments in Mendelian randomization studies. Int. J. Epidemiol. 40, 755-764 (2011).

50. Hemani, G. et al. The MR-Base platform supports systematic causal inference across the human phenome. eLife 7, e34408 (2018).

51. Machiela, M. J. \& Chanock, S. J. LDlink: a web-based application for exploring populationspecific haplotype structure and linking correlated alleles of possible functional variants. Bioinforma. Oxf. Engl. 31, 3555-3557 (2015).

52. Gogarten, S. M. et al. Genetic association testing using the GENESIS R/Bioconductor package. Bioinformatics 35, 5346-5348 (2019).

53. Pritchard, J. K., Stephens, M. \& Donnelly, P. Inference of population structure using multilocus genotype data. Genetics 155, 945-959 (2000).

54. Auton, A. et al. A global reference for human genetic variation. Nature 526, 68-74 (2015).

55. An integrated map of structural variation in 2,504 human genomes | Nature. https://www.nature.com/articles/nature 15394.

56. Hemani, G., Bowden, J. \& Davey Smith, G. Evaluating the potential role of pleiotropy in Mendelian randomization studies. Hum. Mol. Genet. 27, R195-R208 (2018). 
medRxiv preprint doi: https://doi.org/10.1101/2021.01.29.21250759; this version posted February 1, 2021. The copyright holder for this preprint

(which was not certified by peer review) is the author/funder, who has granted medRxiv a license to display the preprint in perpetuity.

All rights reserved. No reuse allowed without permission.

665

666

667

668

669

670

671

672

673

674

675

676

677

678
57. Bowden, J., Davey Smith, G. \& Burgess, S. Mendelian randomization with invalid instruments: effect estimation and bias detection through Egger regression. Int. J. Epidemiol. 44, 512-525 (2015).

58. Bowden, J., Davey Smith, G., Haycock, P. C. \& Burgess, S. Consistent Estimation in Mendelian Randomization with Some Invalid Instruments Using a Weighted Median Estimator. Genet. Epidemiol. 40, 304-314 (2016).

59. Hartwig, F. P., Davey Smith, G. \& Bowden, J. Robust inference in summary data Mendelian randomization via the zero modal pleiotropy assumption. Int. J. Epidemiol. 46, 1985-1998 (2017).

60. Brion, M.-J. A., Shakhbazov, K. \& Visscher, P. M. Calculating statistical power in Mendelian randomization studies. Int. J. Epidemiol. 42, 1497-1501 (2013).

61. Manousaki, D. et al. Genome-wide Association Study for Vitamin D Levels Reveals 69 Independent Loci. Am. J. Hum. Genet. (2020) doi:10.1016/j.ajhg.2020.01.017. 
Table 1. Sample Description for COVID-19 case and comparison groups

\begin{tabular}{|c|c|c|c|c|}
\hline Comparison & Case definition & $\begin{array}{c}\text { Comparison } \\
\text { group definition }\end{array}$ & Sample size & Ancestry \\
\hline $\begin{array}{l}\text { Any COVID-19 } \\
\text { case vs. population } \\
\text { controls }\end{array}$ & $\begin{array}{l}\text { laboratory/physician } \\
\text { confirmed OR self- } \\
\text { reported positive }\end{array}$ & $\begin{array}{l}\text { Everyone that is } \\
\text { not a case (e.g., } \\
\text { the population) }\end{array}$ & $\begin{array}{l}17,965 \text { cases, } \\
1,370,547 \text { controls }\end{array}$ & $\begin{array}{l}93.6 \% \text { EUR } \\
3.1 \% \text { EAS/SAS } \\
1.8 \% \text { AFR } \\
1 \% \text { ARAB } \\
<1 \% \text { AMR } \\
<1 \% \text { HIS }\end{array}$ \\
\hline $\begin{array}{l}\text { Hospitalized } \\
\text { COVID-19 cases vs. } \\
\text { population controls }\end{array}$ & $\begin{array}{l}\text { laboratory/physician } \\
\text { confirmed AND } \\
\text { hospitalized for } \\
\text { COVID-19 }\end{array}$ & $\begin{array}{l}\text { Everyone that is } \\
\text { not a case (e.g., } \\
\text { the population) }\end{array}$ & $\begin{array}{l}7,885 \text { cases, } 961,804 \\
\text { controls }\end{array}$ & $\begin{array}{l}93.7 \% \text { EUR } \\
3.5 \% \text { EAS/SAS } \\
1.1 \% \text { AFR } \\
1.4 \% \text { ARAB } \\
<1 \% \text { AMR } \\
<1 \% \text { HIS }\end{array}$ \\
\hline $\begin{array}{l}\text { Severe respiratory } \\
\text { COVID-19 cases vs. } \\
\text { population controls }\end{array}$ & $\begin{array}{l}\text { laboratory confirmed } \\
\text { AND hospitalized } \\
\text { AND respiratory } \\
\text { support or death }\end{array}$ & $\begin{array}{l}\text { Everyone that is } \\
\text { not a case (e.g., } \\
\text { the population) }\end{array}$ & $\begin{array}{l}4,336 \text { cases, } \\
623,902 \text { controls }\end{array}$ & $\begin{array}{l}99.6 \% \text { EUR } \\
<1 \% \text { AMR }\end{array}$ \\
\hline $\begin{array}{l}\text { COVID-19 positive } \\
\text { cases vs. COVID-19 } \\
\text { negative controls }\end{array}$ & $\begin{array}{l}\text { laboratory/physician } \\
\text { confirmed OR self- } \\
\text { reported positive }\end{array}$ & $\begin{array}{l}\text { laboratory } \\
\text { confirmed OR } \\
\text { self-reported } \\
\text { negative }\end{array}$ & $\begin{array}{l}11,085 \text { cases, } 116,794 \\
\text { controls }\end{array}$ & $\begin{array}{l}86.5 \% \text { EUR } \\
<1 \% \text { EAS/SAS } \\
9.6 \% \text { AFR } \\
3.2 \% \text { HIS }\end{array}$ \\
\hline $\begin{array}{l}\text { Hospitalized vs. } \\
\text { nonhospitalized } \\
\text { COVID-19 }\end{array}$ & $\begin{array}{l}\text { laboratory/physician } \\
\text { confirmed AND } \\
\text { hospitalized for } \\
\text { COVID-19 }\end{array}$ & $\begin{array}{l}\text { Laboratory or } \\
\text { physician } \\
\text { confirmed } \\
\text { COVID-19 }\end{array}$ & $\begin{array}{l}2,430 \text { hospitalized } \\
8,478 \text { nonhospitalized }\end{array}$ & $\begin{array}{l}75.3 \% \text { EUR } \\
<1 \% \text { EAS/SAS } \\
12.6 \% \text { AFR } \\
6.4 \% \text { ARAB } \\
4.7 \% \text { HIS }\end{array}$ \\
\hline
\end{tabular}

AFR $=$ African $; \mathrm{ARAB}=$ Arabic $;$ AMR $=$ Ad Mixed American; EAS $/$ SAS $=$ East Asian/South Asian; EUR = European; HIS = Hispanic 
Table 2. Characteristics of vitamin $D$ instruments and association with measured vitamin D status in UK Biobank ( $\mathrm{N}=\mathbf{4 0 1 , 4 6 0}$, Source: Manousaki et al., 2020)

\begin{tabular}{ccccccccc}
\hline & & & & & & & \multicolumn{2}{c}{ F-statistic } \\
\cline { 6 - 8 } Loci & SNP & EA & NEA & EAF & $\begin{array}{c}\text { veta- } \\
\text { vitD }\end{array}$ & P-vitD & N=10,000 & N=1,300,000 \\
\hline Instrument A & & & & & & & 53 & 6,915 \\
GC & rs11723621 & G & A & 0.29 & -0.19 & $2.9 \mathrm{E}-1689$ & 147 & 19,072 \\
CYP2R1 & rs10832289 & T & A & 0.41 & -0.07 & $2.03 \mathrm{E}-266$ & 23 & 4,597 \\
DHCR7 & rs12803256 & G & A & 0.78 & 0.10 & $1.3 \mathrm{E}-378$ & 35 & 715 \\
CYP24A1 & rs6127099 & T & A & 0.28 & -0.04 & $9.30 \mathrm{E}-62$ & 5 & 6,915 \\
Instrument B & & & & & & & 37 & 4,746 \\
SEC23A & rs8018720 & $\mathrm{C}$ & $\mathrm{G}$ & 0.82 & -0.03 & $4.04 \mathrm{E}-36$ & 3 & 391 \\
AMDHD1 & $\mathrm{rs} 10859995$ & $\mathrm{C}$ & $\mathrm{T}$ & 0.58 & -0.04 & $7.03 \mathrm{E}-89$ & 8 & 983 \\
\hline Instrument C* & & & & & & & 5 & 600 \\
\hline
\end{tabular}

*Characteristics of all SNPs in instrument $\mathrm{C}$ are shown in Supplemental Table 1

Beta-vitD = beta coefficient for association of an additional effect allele with a SD change in serum vitamin $\mathrm{D}$ in the $\log$ scale; $\mathrm{EA}=$ effect allele; $\mathrm{EAF}=$ effect allele frequency; F-statistic = measure of instrument strength, calculated as described in the methods, shown for approximate minimum and maximum sample sizes across the COVID-19 outcomes; NEA = non-effect allele; $\mathrm{P}$-vitD = P-value for the beta coefficient; $\mathrm{SNP}=$ single nucleotide polymorphism 
Table 3. Mendelian Randomization (MR) estimates of effect of vitamin D on COVID-19 outcomes

\begin{tabular}{|c|c|c|c|c|c|c|c|c|c|c|}
\hline \multirow[b]{2}{*}{ MR method } & \multicolumn{2}{|c|}{$\begin{array}{l}\text { COVID vs. } \\
\text { population }\end{array}$} & \multicolumn{2}{|c|}{$\begin{array}{l}\text { Hosp COVID vs. } \\
\text { population }\end{array}$} & \multicolumn{2}{|c|}{$\begin{array}{c}\text { Severe Resp COVID } \\
\text { vs. population }\end{array}$} & \multicolumn{2}{|c|}{$\begin{array}{l}\text { COVID pos vs. } \\
\text { COVID neg }\end{array}$} & \multicolumn{2}{|c|}{$\begin{array}{l}\text { Hosp COVID vs. } \\
\text { non-hosp COVID }\end{array}$} \\
\hline & OR & $95 \% \mathrm{CI}$ & OR & $95 \% \mathrm{CI}$ & OR & $95 \% \mathrm{CI}$ & OR & $95 \% \mathrm{CI}$ & OR & $95 \% \mathrm{CI}$ \\
\hline \multicolumn{11}{|l|}{ Instrument $\mathrm{A}$} \\
\hline IVW & 1.04 & $0.92-1.18$ & 1.05 & $0.84-1.31$ & 0.96 & $0.64-1.43$ & 1.15 & $0.99-1.35$ & 1.44 & $0.75-2.78$ \\
\hline MR-Egger intercept test & \multicolumn{2}{|c|}{$\mathrm{p}$-value $=0.57$} & \multicolumn{2}{|c|}{$\mathrm{p}$-value $=0.19$} & \multicolumn{2}{|c|}{$\mathrm{p}$-value $=0.14$} & \multicolumn{2}{|c|}{$\mathrm{p}$-value $=0.88$} & \multicolumn{2}{|c|}{$\mathrm{p}$-value $=0.14$} \\
\hline \multicolumn{11}{|l|}{ Instrument B } \\
\hline IVW & 1.04 & $0.92-1.18$ & 1.15 & $0.92-1.44$ & 1.01 & $0.71-1.43$ & 1.15 & $0.98-1.34$ & 1.42 & $0.86-2.35$ \\
\hline MR-Egger intercept test & \multicolumn{2}{|c|}{$\mathrm{p}$-value $=0.62$} & \multicolumn{2}{|c|}{$\mathrm{p}$-value $=0.15$} & \multicolumn{2}{|c|}{$\mathrm{p}$-value $=0.06$} & \multicolumn{2}{|c|}{ p-value $=0.61$} & \multicolumn{2}{|c|}{$\mathrm{p}$-value $=0.14$} \\
\hline \multicolumn{11}{|l|}{ Instrument $\mathrm{C}$} \\
\hline IVW & 1.02 & $0.90-1.15$ & 1.12 & $0.92-1.37$ & 1.05 & $0.82-1.34$ & 1.05 & $0.92-1.20$ & 1.23 & $0.85-1.77$ \\
\hline MR-Egger intercept test & \multicolumn{2}{|c|}{$\mathrm{p}$-value $=0.88$} & \multicolumn{2}{|c|}{$\mathrm{p}$-value $=0.85$} & \multicolumn{2}{|c|}{$\mathrm{p}$-value $=0.23$} & \multicolumn{2}{|c|}{$\mathrm{p}$-value $=0.12$} & \multicolumn{2}{|c|}{$\mathrm{p}$-value $=0.14$} \\
\hline \multicolumn{11}{|c|}{ Instrument of risk of vitamin D deficiency } \\
\hline IVW & 1.00 & $0.99-1.01$ & 1.00 & $0.98-1.02$ & 1.02 & $0.99-1.05$ & 0.99 & $0.97-1.00$ & 0.97 & $0.90-1.05$ \\
\hline MR-Egger intercept test & \multicolumn{2}{|c|}{$\mathrm{p}$-value $=0.95$} & \multicolumn{2}{|c|}{$\mathrm{p}$-value $=0.61$} & \multicolumn{2}{|c|}{$\mathrm{p}$-value $=0.92$} & \multicolumn{2}{|c|}{$\mathrm{p}$-value $=0.46$} & \multicolumn{2}{|c|}{$\mathrm{p}$-value $=0.21$} \\
\hline \multicolumn{11}{|c|}{ Instrument of risk of vitamin D insufficiency } \\
\hline IVW & 1.00 & $0.99-1.01$ & 1.00 & $0.98-1.02$ & 1.06 & $1.00-1.05$ & 0.99 & $0.98-1.00$ & 0.97 & $0.90-1.05$ \\
\hline MR-Egger intercept test & \multicolumn{2}{|c|}{$\mathrm{p}$-value $=0.87$} & \multicolumn{2}{|c|}{$\mathrm{p}$-value $=0.64$} & \multicolumn{2}{|c|}{$\mathrm{p}$-value $=0.76$} & \multicolumn{2}{|c|}{$\mathrm{p}$-value $=0.59$} & p-valı & $=0.22$ \\
\hline
\end{tabular}

$\mathrm{OR}=$ odds ratio representing change in risk of outcome per SD increase in log-transformed serum vitamin D (Instruments A, B and C) or difference in risk of outcome for individuals at risk of vitamin D deficiency/insufficiency vs. individuals with sufficient vitamin D; $95 \%$ CI, 95\% confidence interval 
medRxiv preprint doi: https://doi.org/10.1101/2021.01.29.21250759; this version posted February 1, 2021. The copyright holder for this preprint (which was not certified by peer review) is the author/funder, who has granted medRxiv a license to display the preprint in perpetuity.

All rights reserved. No reuse allowed without permission.

Figure 1) Schematic of two-sample MR study design

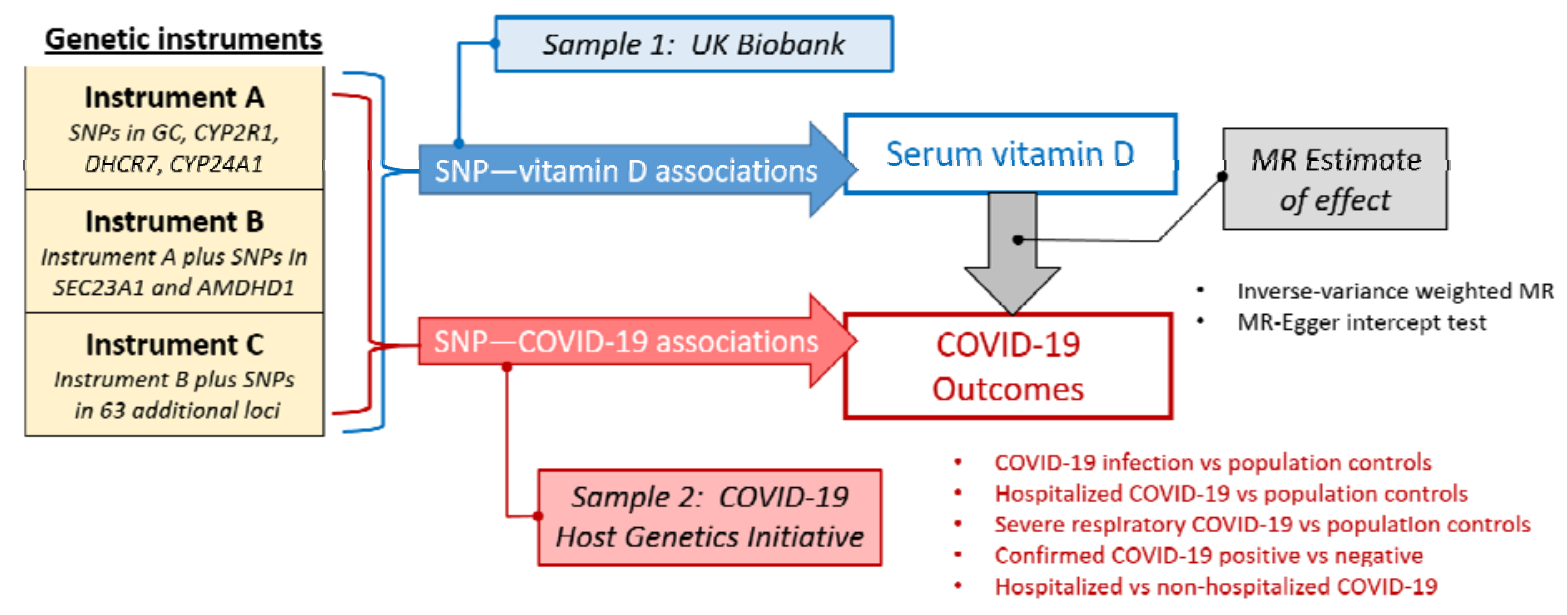


medRxiv preprint doi: https://doi.org/10.1101/2021.01.29.21250759; this version posted February 1, 2021. The copyright holder for this preprint (which was not certified by peer review) is the author/funder, who has granted medRxiv a license to display the preprint in perpetuity.

Figure 2) Inverse variance weighted MR estimates for effect of serum vitamin D on risk of COVID19 outcomes

COVID-19 outcome

\section{COVID vs. Population}

Instrument A

Instrument B

Instrument C

Hospitalized COVID vs. Population

Instrument $A$

Instrument B

Instrument $C$

Severe Respiratory COVID vs. Population

Instrument A

Instrument B

Instrument C

COVID vs. Confirmed COVID-Negative

Instrument $A$

Instrument B

Instrument $C$

Hospitalized vs. Non-Hospitalized COVID

Instrument $\mathrm{A}$

Instrument B

Instrument $\mathrm{C}$
OR [ $95 \% \mathrm{Cl}]$

$1.04[0.92,1.18]$

$1.04[0.92,1.18]$

$1.02[0.90,1.15]$

$1.05[0.84,1.31]$

$1.15[0.92,1.44]$

$1.12[0.92,1.37]$

$0.96[0.64,1.43]$

$1.01[0.71,1.43]$

$1.05[0.82,1.34]$

$1.15[0.99,1.35]$

$1.15[0.98,1.34]$

$1.05[0.92,1.20]$

$1.44[0.75,2.78]$

$1.42[0.86,2.35]$

$1.23[0.85,1.77]$

\begin{tabular}{|c|c|c|c|c|}
\hline Г & $\mathrm{T}$ & ? & $\mid$ & 7 \\
\hline-1 & 0 & 1 & 2 & 3 \\
\hline
\end{tabular}

3 
medRxiv preprint doi: https://doi.org/10.1101/2021.01.29.21250759; this version posted February 1, 2021. The copyright holder for this preprint (which was not certified by peer review) is the author/funder, who has granted medRxiv a license to display the preprint in perpetuity. All rights reserved. No reuse allowed without permission.

Figure 3) Inverse variance weighted MR estimates for effect of vitamin D insufficiency or deficiency on risk of COVID-19 outcomes

COVID-19 outcome

OR $[95 \% \mathrm{Cl}]$

COVID vs Population

vitamin $D$ deficiency

vitamin D insufficiency

Hospitalized COVID vs Population

vitamin $\mathrm{D}$ deficiency

vitamin D insufficiency

Severe Respiratory COVID vs Population

vitamin $\mathrm{D}$ deficiency

vitamin D insufficiency

COVID vs Confirmed COVID-Negative

vitamin $\mathrm{D}$ deficiency

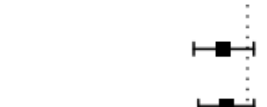

vitamin D insufficiency

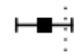

$0.99[0.97,1.00]$

$0.99[0.98,1.00]$

Hospitalized vs Non-Hospitalized COVID

vitamin $\mathrm{D}$ deficiency

vitamin D insufficiency

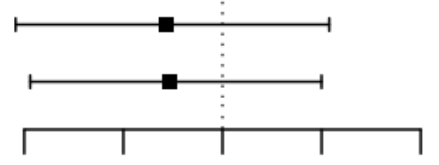

$0.97[0.90,1.05]$

$0.97[0.90,1.05]$

$\begin{array}{lllll}0.9 & 0.95 & 1 & 1.05 & 1.1\end{array}$

OR $[95 \% \mathrm{Cl}]$ for COVID-19 outcome by vitamin D status (ref=vitamin D sufficiency) 